\title{
Inhibiting Factors in the Administration of Education (Senior High School) in Kepulauan Riau Province
}

\author{
Auly Fikry, Endang Larasati, Ida hayu Dimawati \\ Magister of Public Administration, Diponegoro Unviersity \\ Email: aulyfikry@gmail.com
}

(Received: September 1-2019; revised: September 16-2019; published: December 31-2019)

\begin{abstract}
The policy for transfer of authority to manage high schools from district or city government to provincial governments, in its implementation, experienced various kinds of obstacles. As in the Riau Islands province, with the number of islands reaching 394 inhabited islands scattered throughout the Riau Islands region, the transfer of authority from the district / city to the province will have some changes that must be made. The purpose of this study is to examine the management of high school education in the Riau Archipelago. The research method used is qualitative, data collection is done through interviews and observations. The results showed that there were two factors which became obstacles in the management of senior high school education in the Riau Islands, namely the geographical environment and the national education system. The results showed that the geographical environment of the archipelago which has a $95 \%$ sea area had several impacts in running.
\end{abstract}

Keywords: education management; High School; Archipelago Region

\section{INTRODUCTION}

Education is the main supporting factor for the formation of productive human beings and has the skills to create a prosperous and prosperous society and compete not only at the national level but also at the international level (Niswaty, Rusbiati, Jamaluddin, \& Salam, 2017; Saggaf, Salam, \& Rifka, 2017). According to Lee (1995) is a process in which people with education intentionally transform their cultural heritage, namely knowledge, values and skills from time to time. Education is a pillar for a country to develop a nation. Education itself according to Triwiyanto (2017) Education is a conscious effort made by the community and the government through teaching, guidance and training that takes place at school and outside of school for the whole life to prepare students to be able to play their role in the environment in the right life in the future. This is in accordance with the 1945 Constitution article 31 paragraph (1) and paragraph (2) which reads: (1) Every citizen has the right to get Education, (2) Every citizen must follow basic education and the government is obliged to finance it.

Another policy governing education is the National Medium-Term Development Plan (RPJMN) for 2015-2019. The objectives of this RPJMN relating to Education are: (1) Increase the participation rate of primary and secondary education, (2) Increase the sustainability rate of education marked by decreasing dropout rates and continuing rates, (3) Reducing the gap in education participation between community groups, especially between rich and poor residents, between male and female residents, between urban and rural areas and between regions. (4) Increase the readiness of secondary education students to enter the job market or to continue to tertiary education. 
270|Jurnal Ilmiah Ilmu Administrasi Publik: Jurnal Pemikiran dan Penelitian Administrasi Publik Volume 9 Number 2, July- December 2019. Page 169-276

Based on the objectives of the RPJMN, specifically in the second and fourth objectives, it is stated that the government is serious in eradicating the number of dropouts in all regions of Indonesia and increasing the readiness of secondary education to enter the labor market or to further the tertiary education level. Therefore the Government of Indonesia is trying to change some of the existing education systems in order to improve the quality of Education (Akib, Guntur, \& Salam, 2016; Saggaf, Akib, Salam, Baharuddin, \& Kasmita, 2018; Saggaf, Aras, et al., 2018; Saggaf \& Salam, 2017).

Since the era of policy reforms in the field of education has experienced a variety of changes, one of the most recent is the occurrence of changes in government affairs in the field of education with the enactment of Law No. 23 of 2014 concerning Regional Government. The law mandates the management authority of Senior High Schools (SMA) and Vocational High Schools (SMK) which were previously handed over to the district / city government, the mandate of this policy began to be carried out in March 2016, and it should begin to apply to all of Indonesia in October 2017.

There are several articles from Law Number 23 of 2014 concerning Regional Government that are important to be reviewed, including articles 9,11,12 and 15. Article 9 states that government affairs are divided into absolute, concurrent, and general government affairs. What is meant by absolute government affairs is the full authority of the central government, concurrent affairs are functions which are divided into the central government and provincial and district / city governments. General government affairs are government affairs which become the authority of the President as head of government. Various forms of government affairs in accordance with article 9 of Law No. 23 of 2014 as shown in Table 1 below:

\section{Table 1}

\section{Education Management Indonesia}

\begin{tabular}{|l|l|l|l|}
\hline Sub Affair & Central Goverment & Province Goverment & \multicolumn{1}{c|}{$\begin{array}{c}\text { Regency/city } \\
\text { Regional }\end{array}$} \\
\hline $\begin{array}{l}\text { Education } \\
\text { Management }\end{array}$ & $\begin{array}{l}\text { 1. Establish national } \\
\text { education standards } \\
\text { 2. Management of } \\
\text { university education }\end{array}$ & $\begin{array}{l}\text { Management } \\
\text { special secondary } \\
\text { education }\end{array}$ & $\begin{array}{l}\text { Management of basic } \\
\text { education, early age, } \\
\text { dan non formal } \\
\text { education }\end{array}$ \\
\hline
\end{tabular}

Source: Law Number 23 of 2014 (processed by research)

There is a change of authority in managing senior high school and vocational high school education from regency to province. In this case from the District and city education offices to the Riau Islands Province Education Office as related institutions of education management carried out in the Riau Islands. Of course the transfer of authority is also faced with various obstacles in its implementation in various regions in Indonesia, one of which is the Riau Islands Province. 
Riau Islands was formed in 2002 and is the 32nd province in Indonesia. Riau Islands Province is one of the provinces which is an archipelago in Indonesia. Riau Islands BPS data (2017) shows that the number of islands in Riau Islands is 1796 islands. Complete data from the islands in the Riau Islands Province as shown in Table 2.

\section{Tabel 2}

\section{The Number of Island in Kepulauan Riau Province}

\begin{tabular}{clcc}
\hline Number & Regency/City & Number of Islands & Inhabited \\
\hline 1 & Batam city & 371 & 133 \\
2 & Tanjungpinang City & 9 & 2 \\
3 & Bintan Regency & 241 & 48 \\
4 & Karimun Regency & 251 & 73 \\
5 & Natuna Regency & 392 & 62 \\
6 & Lingga dan Anambas Regency & 532 & 76 \\
\hline \multicolumn{2}{r}{ Total } & 1796 & 394 \\
\hline
\end{tabular}

Source: Central Bureau of Statistics (Badan Pusat Statistik /BPS) Kepulauan Riau 2017

Looking at table 1.2 which states that there are 1796 islands in Riau Islands and 394 inhabited islands, researchers say this is quite unique. The large number of islands and the extent of coverage, where the province has a land area less than the total sea, about $95 \%$ of the ocean and the rest of the land. With these conditions, of course, the situation of education will be very different from other regions in Indonesia. With the ocean being very dominant compared to the amount of land available, of course the educational methods applied should be determined according to the conditions of each region. This geographical situation makes Riau Islands unique, especially with regard to senior high school education management.

According to Usman (2013) the factors that influence management are the Environment, Educational Organizations, and National Education System. One reason for using the theory put forward by Usman is because the research locus of researchers in the relevant department does not make schools the main focus, it is simpler to want to see how the impact of changing the authority of secondary education that was previously managed by the city / regency related to the province .

Frederiks, Stenner, \& Hobman (2015) explains in a broad sense the environment includes residence, climate and geography, residence, customs, and knowledge. The environment is everything that is seen and contained in terms of life that always develops from one era to another. While the national education system can be seen from the national education (Law No. 20/2003) which states that national education is education based on the Pancasila and the 1945 Constitution of the Republic of Indonesia which is rooted in religious values, the national culture of Indonesia and is responsive to demands for change era. From this understanding it is very clear that Indonesian national education has values that are based on national religion and culture.

The existence of various factors that also influence management activities and also the conditions of the unique region of the Ria Islands Province, because the geographical condition of this Province is slightly different from other regions in Indonesia. With the spread of this area 


\author{
272 Jurnal Ilmiah Ilmu Administrasi Publik: Jurnal Pemikiran dan Penelitian Administrasi Publik \\ Volume 9 Number 2, July- December 2019. Page 169-276
}

which is quite difficult to reach, it would be very interesting to see how the management of high school and vocational high school level whose management authority is transferred to the Province. Research on management of secondary school education has also been carried out by Muhdi, Kastawi, \& Widodo (2017) where the results of his research indicate that the transfer of authority is expected to be able to improve the quality of education, improve access and equity in education. The challenge faced is that the Province will ignore the welfare of non-civil servant teachers and reduce free education at the secondary level. And finally it is recommended that the government make government regulations on middle management education.

\title{
METHOD
}

This research according to the type and data collected is a qualitative study with descriptive methods. Descriptive research can not only describe or describe it, but can also describe conditions in their developmental stages. According to Creswell \& Creswell (2017) qualitative methodology as a research procedure that produces descriptive data in the form of written or oral words from people and observable behavior. This research uses descriptive qualitative research method Sukmadinata (2012) says that "descriptive research is a method that aims to describe the phenomena that exist, which took place in the past or present".

Qualitative research, the instrument is the researcher himself. The main data sources in qualitative research are primary data and secondary data. Primary data sources are data obtained directly from the field and are still raw data. Secondary data sources are sources of data obtained from literature studies and documentation studies. According to Satori and Komariah (2010) the determination of informant data sources is purposive, that is determined by adjusting to the research objectives or specific objectives. The informants in this study were the Riau Islands Province Education Agency and six school principals in Tanjungpinang and Bintan. Data collection techniques in this study are interviews, observation, and study documentation. The analysis technique in this study is a qualitative data analysis technique following the concept of (Miles, Huberman, \& Saldana, 2014), namely data collection, data condensation, data reduction, conclusion and verification.

\section{RESULT AND DISCUSSION}

Education Management is a systematic and comprehensive process of cooperation to realize the goals of national education. Management of education itself can also be interpreted as everything that is concerned with managing the educational process (Gaffar, 2009). The transfer of authority in the management of education in senior high schools from urban district crossers to the provincial government in the Riau Islands Province in its implementation has experienced various obstacles. The results showed that there were two factors which became obstacles in the management of high school education in the Provincial Government, which in the case of the Riau Islands Provincial Education Office, namely; (1) geographical environment and (2) national education system. 


\section{The Geographical Environment of the Riau Islands Regarding High School Education Management}

The environment is all things and conditions, including humans and their activities, which are contained in the space in which humans are and affect the survival and well-being of humans and other living bodies. This environmental factor can also be seen one of them from the geographical conditions in a region. Therefore this environment is one of the factors in the management of education in the Riau Islands Province. Based on the results of the study it can be found that environmental factors that influence in the management of education in Riau Islands Province are geographical conditions. In accordance with the results of the interview with the Principal of SMAN 1 Tanjung Pinang:

"Geographical conditions will certainly greatly determine the quality of education in a region, because when different fields will be different things that should be applied, there will be some regions that are lagging behind other regions, for example Indonesia itself must be recognized that the quality of education in Java will be better compared to other regions in Indonesia, it is undeniable that our region is $90 \%$ more ocean than the land area, of course processes such as teacher training, book distribution, and costs are different in each region, for example Natuna whose basic food prices can only doubled compared to the Tanjung Pinang city area. "(interview results 03-02-2019)

The same thing was also expressed related to geographical conditions being one of the factors in education management in Riau Islands Province, according to the results of an interview with the Head of the Field of Development

"Geography is indeed an important factor in the quality of an area, for example the island of Java which is no longer a public secret so dominates education in Indonesia. The range of control that is quite far between one island and another island in my opinion is indeed a dilemma in this province not to mention travel costs are so high. "(interview results 0312-2019)

Based on the results of interviews and observations in the field geographical conditions will certainly greatly determine the quality of education in an area, because when different fields will be different things that should be applied, there will be some areas that are lagging behind compared to other regions. it is undeniable that the Riau Islands region, which is $95 \%$ more than the ocean, compared to the size of its land area, will be very influential in the management of education. Problems that arise such as access to education of the Riau Islands Province are not very evenly distributed to each region.

Therefore this environmental factor is an inhibiting factor in the management of education in the Riau Islands Province. Geography is indeed an important factor in the quality of an area, for example the island of Java which is no longer a secret so dominates education in Indonesia. The range of control that is quite far between one island and another island in my opinion is indeed a dilemma in this province not to mention the costs travel so high. In addition, geographical conditions will certainly determine the quality of education in a region, because when different fields will be different things that should be applied, there will be some regions that are lagging behind other regions, for example Indonesia itself must be recognized that the quality of education in Java will be better compared to other regions in Indonesia, it is 
274 Jurnal Ilmiah Ilmu Administrasi Publik: Jurnal Pemikiran dan Penelitian Administrasi Publik Volume 9 Number 2, July- December 2019. Page 169-276

undeniable that our region is $90 \%$ more ocean than the land area, of course processes such as teacher training, book distribution, and costs are different in each region, for example Natuna with food prices the principal can be doubled compared to the Tanjungpinang city area.

\section{National Education System Regarding the Management of Education of Upper Middle Schools in Riau Islands}

The national education system is the whole component of education that is interrelated in an integrated manner to achieve the goals of national education, the National Education System is a guideline for education administrators or managers to behave, both individually and in groups so that the relationship between people and people and people with the organization becomes orderly. The interview results are in accordance with the results of the interview with the Principal of SMAN 4

"With the change in the national education system, which now has the authority given to the provincial government to regulate senior secondary education, there are of course some new things, for example the MKKS (Principal Conference). MKKS was formed after the enactment of the policy of Law No. 23 of 2014, with the aim of facilitating coordination between the department and the school. If directly related to the reasons for children dropping out of school with this national policy, of course it is necessary to do a more in-depth study related to that. "(Interview 04-04-2019)

Other information was also obtained based on the results of interviews with the Head of High School Development

"The most fundamental difference from the transfer of authority in question is the difficulty in the management process, especially in terms of supervision, it must be recognized that controlling all schools in the Riau Islands Province is not easy, not to mention related to this education is something that sometimes has enough problems complex. And regarding the increasing number of school dropouts in the Riau Islands in 2018 , it is necessary to carry out a special scientific study related to the main cause, in my personal opinion today's teenagers are lulled by technological advancements that tend to facilitate each of their activities, not to mention the juvenile delinquency which is getting day by day more widespread "(interview results 03-12-2019)

Based on the results of the study found that the national education system is one of the inhibiting factors in the management of education in the Riau Islands Province Education Office, this is due to the change in the national education system that is now given authority to the provincial government to regulate senior secondary education. new and need adjustments such as the formation of MKKS, where MKKS was formed after the enactment of the Act No. 23 of 2014, with the aim of facilitating coordination between the provincial office with the school. Besides that, the problems related to school dropouts, I think, still need to be reviewed in fact what causes them to drop out of school, with the education system that also provides free assistance for those who are less able, this should be very helpful. As for the implementation of the new policy related to the transfer of high school authority to the Province with the increasing 
number of dropouts in Riau Islands Province, more in-depth research needs to be done. The most fundamental difference from the transfer of authority in question is the difficulty in the management process, especially in terms of supervision, it must be recognized that controlling all schools in Riau Islands Province is not easy, not to mention related to education is something that sometimes has enough problems complex. Regarding the increasing number of school dropouts in the Riau Islands in 2018, it is necessary to conduct a special scientific study related to the main cause, in my personal opinion today's teenagers are lulled by technological advancements that tend to facilitate their activities, not to mention the delinquency of adolescents who are increasingly getting more and more bloom. The facts that occur in the field when changing authority must, of course, be more complex in the school that I lead myself these past few years is quite good and almost no students drop out of school, with juvenile delinquency at this time and this globalized era is quite difficult for the school to control them in such a way.

\section{CONCLUSION}

The intended environment here is more geographical of Riau Islands, which is 95 percent more territorial waters than terrestrial areas, which will greatly affect the management of education, processes such as teacher training, distribution of books, and costs that differ in each region. With the range of control in managing high school in Riau Islands, management needs to be different from other regions. The existing national education system is actually sufficient to help students, especially in terms of education costs, the enactment of Law No. 23 of 2014 is intended to improve the quality of education so that there is a separation of the focus of the city administration to take care of primary and junior secondary schools while the provinces take care of senior secondary schools, but for the Riau Islands region, the above should be reviewed or there are certain rules for areas that have much less land area with sea areas. As for the related increase in high school dropouts that occur in the Riau Islands based on the results of research there is still a need for deeper study of the schools or children concerned.

\section{REFERENCES}

Akib, H., Guntur, M., \& Salam, R. (2016). Civitas Academic Perception of "Blissful Services" for Recipient Postgraduate Program State University of Makassar, Indonesia. International Conference on Public Organization VI (ICONPO VI), 340-350. Thammsat University, Tha Prachan Campus.

Creswell, J. W., \& Creswell, J. D. (2017). Research design: Qualitative, quantitative, and mixed methods approaches. Sage publications.

Frederiks, E., Stenner, K., \& Hobman, E. (2015). The socio-demographic and psychological predictors of residential energy consumption: A comprehensive review. Energies, 8(1), 573-609.

Gaffar, M. F. (2009). Pembiayaan Pendidikan Nasional. Handout Perkuliahan Pembiayaan 
276|Jurnal Ilmiah Ilmu Administrasi Publik: Jurnal Pemikiran dan Penelitian Administrasi Publik Volume 9 Number 2, July- December 2019. Page 169-276

Pendidikan PPS Program Doktor Administrasi Pendidikan Universitas Pendidikan Indonesia.

Lee, C. D. (1995). A culturally based cognitive apprenticeship: Teaching African American high school students skills in literary interpretation. Reading research quarterly, 608-630.

Miles, M. ., Huberman, A. ., \& Saldana, J. (2014). Qualitative Data Analysis, A Methods Sourcebook (3 ed.; Tjetjep Rohindi Rohidi, Ed.). Jakarta: UI-Press.

Muhdi, M., Kastawi, N. S., \& Widodo, S. (2017). Teknik Pengambilan Keputusan Dalam Menentukan Model Manajemen Pendidikan Menengah. Kelola: Jurnal Manajemen Pendidikan, 4(2), 135-145.

Niswaty, R., Rusbiati, S., Jamaluddin, J., \& Salam, R. (2017). The Influence of Teacher's Reinforcement for Students Motivation. International Conference on Education, Science, Art and Technology, 148-152.

Saggaf, M. S., Akib, H., Salam, R., Baharuddin, A., \& Kasmita, M. (2018). The Quality Analysis Of Academic Services.

Saggaf, M. S., Aras, M., Akib, H., Salam, R., Baharuddin, A., \& Kasmita, M. (2018). The Quality Analysis of Academic Services Based on Importance Performance Analysis (IPA).

Saggaf, M. S., \& Salam, R. (2017). Examining Academic Service using Importance Performance Analysis (IPA).

Saggaf, M. S., Salam, R., \& Rifka, R. (2017). The Effect of Classroom Management on Student Learning Outcomes. International Conference on Education, Science, Art and Technology, 98-102.

Sukmadinata, N. S. (2012). Metode Penelitian Pendidikan, PT Remaja Rosdakarya. Bandung.

Triwiyanto, T. T. (2017). Regrouping of Schools within One Complex and Teacher Redistribution to Attain Equitable Management and Distribution of Teachers. 2nd International Conference on Educational Management and Administration (CoEMA 2017). Atlantis Press.

Usman, M. I. (2013). Pesantren Sebagai Lembaga Pendidikan Islam (Sejarah Lahir, Sistem Pendidikan, Dan Perkembangannya Masa Kini). Jurnal al-Hikmah, 14(1), 127-146. 